\title{
Sherd Assemblages from Sites in Bowie, Cass, Gregg, Lamar, and Red River Counties in East Texas Held by the Sam Noble Oklahoma Museum of Natural History
}

Timothy K. Perttula

Heritage Research Center, Stephen F. Austin State University

Bo Nelson

Heritage Research Center, Stephen F. Austin State University

Follow this and additional works at: https://scholarworks.sfasu.edu/ita

Part of the American Material Culture Commons, Archaeological Anthropology Commons, Environmental Studies Commons, Other American Studies Commons, Other Arts and Humanities Commons, Other History of Art, Architecture, and Archaeology Commons, and the United States History Commons

Tell us how this article helped you.

This Article is brought to you for free and open access by the Center for Regional Heritage Research at SFA ScholarWorks. It has been accepted for inclusion in Index of Texas Archaeology: Open Access Gray Literature from the Lone Star State by an authorized editor of SFA ScholarWorks. For more information, please contact cdsscholarworks@sfasu.edu. 


\section{Sherd Assemblages from Sites in Bowie, Cass, Gregg, Lamar, and Red River Counties in East Texas Held by the Sam Noble Oklahoma Museum of Natural History}

Creative Commons License

(c) $(1)$ ( 8

This work is licensed under a Creative Commons Attribution-NonCommercial 4.0 International License 


\title{
Sherd Assemblages from Sites in Bowie, Cass, Gregg, Lamar, and Red River Counties in East Texas Held by the Sam Noble Oklahoma Museum of Natural History
}

\author{
Timothy K. Perttula and Bo Nelson
}

\section{Introduction}

The Sam Noble Oklahoma Museum of Natural History (SNOMNH) has in their collections several assemblages of ancestral Caddo ceramic vessel sherds from sites in East Texas. We recently had an opportunity to examine and document these collections during a trip to the SNOMNH, and in this article, we put those findings on record.

\section{Sherd Assemblages}

In this article, we discuss ancestral Caddo vessel sherd assemblages in the SNOMNH from seven sites in Bowie, Cass, Gregg, Lamar and Red River counties in East Texas. Five of the assemblages are from recorded archaeological sites, but the two sites in Bowie County have not yet been officially recorded and their exact locations are not known at the present time.

\section{Aiken Creek site, Bowie County}

Aiken Creek is a southward-flowing tributary of the Sulphur River that enters the river about one mile east of the dam at Lake Wright Patman. It is not known from where on the creek this collection of sherds came, but they were collected by M. P. Miroir, Jr., a well-known collector and avocational archaeologist. It is possible that these vessel sherds are from the Molly Cameron site (41BW18), a wellknown Caddo settlement and cemetery on Aiken Creek (Perttula 2017a).

Miroir collected 16 ceramic vessel sherds from the Aiken Creek site (Table 1). They are from either grog-tempered (94 percent) or grog-bone-tempered (6 percent) wares; the one grog-bone-tempered sherd is from a utility ware vessel with horizontal incised lines.

Table 1. Ceramic assemblage from the Aiken Creek site in Bowie County, Texas.

\begin{tabular}{lccc}
\hline Ware & Grog-tempered & Grog-bone-tempered & N \\
\hline Plain & 3 & - & 3 \\
Utility & 6 & 1 & 7 \\
Fine & 6 & - & 6 \\
\hline Totals & 15 & 1 & 16 \\
\hline
\end{tabular}

Sherds with brushed elements comprise 31 percent of the assemblage, and they include sherds that also have incised lines, punctated rows, and appliqued fillets (Table 2 and Figure 1a, c); these sherds are likely from Pease Brushed-Incised vessels (see Suhm and Jelks 1962:Plate 60). Another sherd has 
horizontal incised lines on the rim, a row of tool punctations at the rim-body juncture, and vertical brushing marks on the vessel body (Figure 1b).

Table 2. Decorative methods and elements in the utility ware and fine ware sherds from the Aiken Creek site assemblage.

\begin{tabular}{llll}
\hline Decorative method and element & Rim & Body & $\mathrm{N}$ \\
\hline
\end{tabular}

\section{Utility Ware}

Brushed-Incised

opposed brushed-incised marks and lines

Brushed-Incised-Punctated

upper and lower tool punctated rows with horizontal

brushed-incised zone between

\section{Brushed-Punctated-Appliqued}

upper and lower fingernail punctated rows with

horizontal brushing marks between; vertical brushed

body and vertical appliqued fillets

\section{Incised}

horizontal incised lines

\section{Incised-Punctated}

curvilinear and semi-circular incised zones filled with circular punctations

horizontal incised lines and tool punctated row between the lines

\section{Incised-Punctated-Brushed}

horizontal incised lines [rim]-tool punctated row

at rim-body juncture-vertical brushed [body]

\section{Fine Ware}

\section{Engraved}

concentric circle el.

curvilinear engraved lines

curvilinear-circular-diagonal-and triangular engraved lines and elements

straight engraved line

triangle el. with vertical hatched lines

\section{Engraved-Punctated}

horizontal-vertical engraved lines and row of excised punctations (Barkman Engraved) 


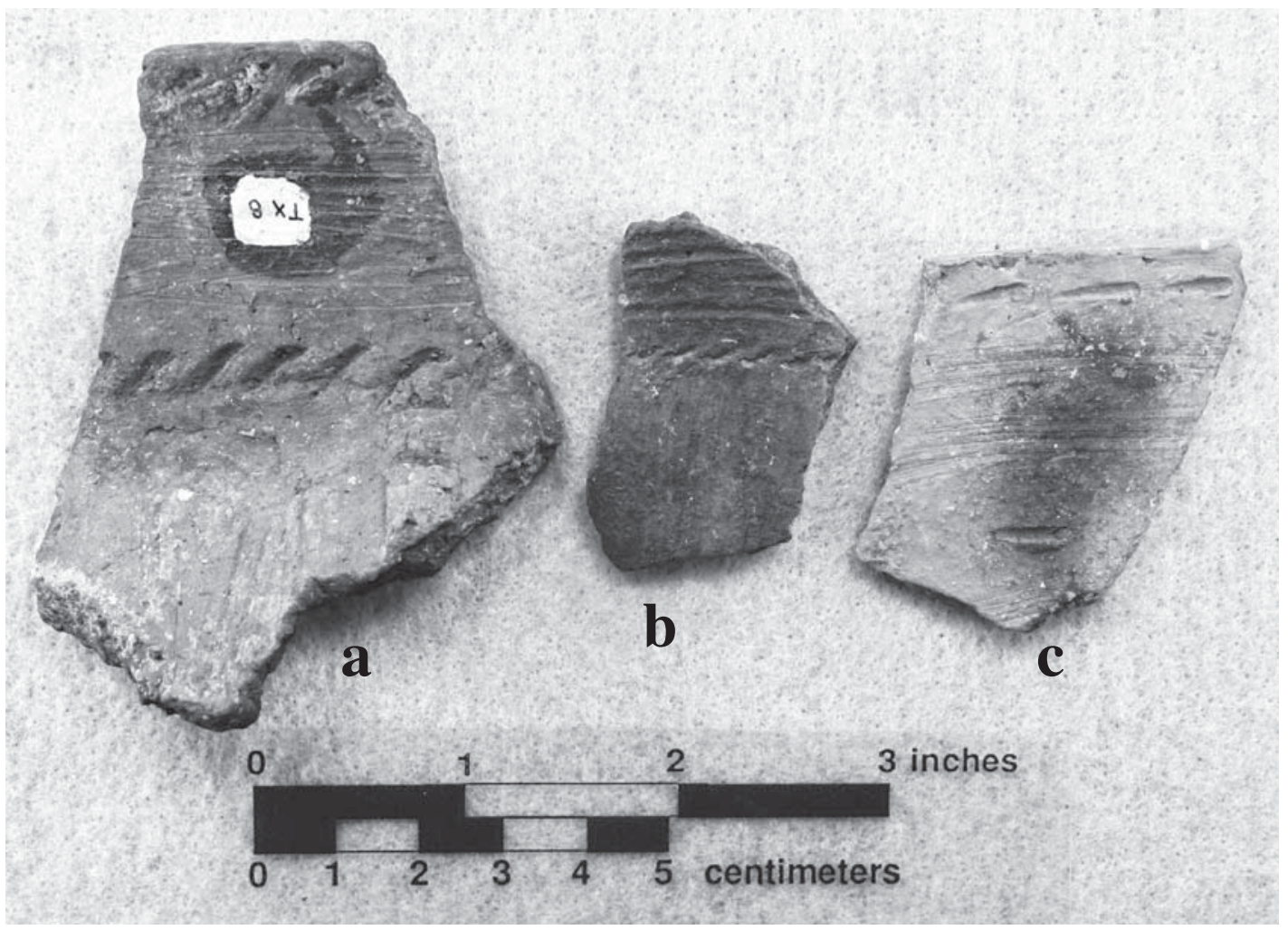

Figure 1. Utility ware sherds from the Aiken Creek site: a, brushed-punctated-appliqued; b-c, incised-punctated-brushed.

One distinctive incised-punctated body sherd in the Aiken Creek site collection has semi-circular and curvilinear incised zones filled with cane punctations (Figure 2b). It is likely from a Crockett Curvilinear Incised bowl (see Suhm and Jelks 1962:Plate 17).

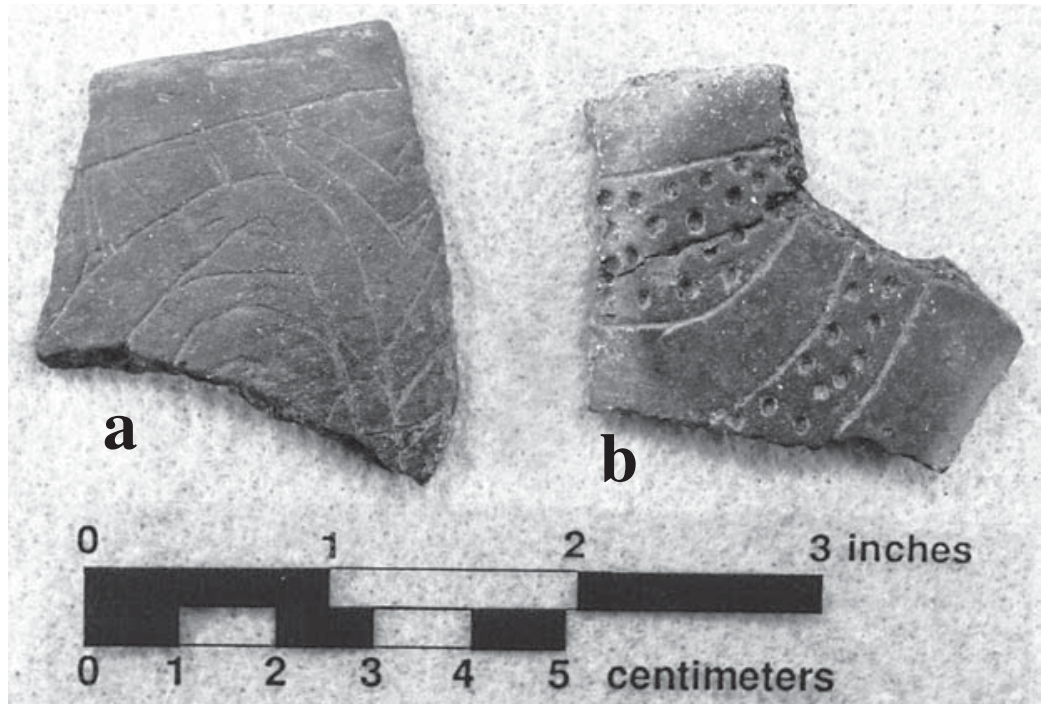

Figure 2. Engraved and incised-punctated sherds from the Aiken Creek site: a, Hatchel Engraved rim; b, Crockett Curvilinear Incised body sherd. 
The fine ware engraved sherds at the site have concentric circles, curvilinear lines, triangles with vertical hatched lines, and a rim sherd with curvilinear, circular, and diagonal engraved lines as well as triangle elements (see Figure 2a). This rim may be from a Hatchel Engraved vessel (see Suhm and Jelks 1962:67). One body sherd is from a Barkman Engraved vessel with horizontal and vertical engraved lines and a horizontal row of excised punctations (see Table 2).

The decorated sherds in the Aiken Creek site assemblage suggest that the site had two periods of Caddo settlement. The first, dating to the Early Caddo period (ca. A.D. 1000-1200), is marked by a rim with horizontal incised lines and a Crockett Curvilinear Incised rim sherd. The later occupation was during the Late Caddo period Texarkana phase, perhaps sometime between ca. A.D. 1400-1550. The distinctive sherds associated with this component are from Barkman Engraved, Hatchel Engraved, and Pease Brushed-Incised vessels.

\section{Emerald Post Farm, Bowie County}

At this time, the exact location of the Emerald Post Farm site in Bowie County is not known, but land records searched to locate the Post family lands in the county indicate that their lands overlook McKinney Bayou to the north, only a few miles from the Arkansas state line and not far east of the Texas A\&M University at Texarkana campus (Lawrence Head, October 2017 personal communication). The landforms overlooking the Bayou would have been prime settlement locations for ancestral Caddo peoples. The sherds at SNOMNH from the site were collected and donated by Pete Miroir. The 19 sherds in the small assemblage are tempered primarily with grog ( 89 percent), with grog-bone ( 5 percent), and bone-hematite-temper (5 percent) accounting for the remainder of the sherds (Table 3 ).

Table 3. Ceramic assemblage from the Emerald Post Farm site in Bowie County, Texas.

\begin{tabular}{lcccc}
\hline Ware & Grog-tempered & Grog-bone-tempered & $\begin{array}{c}\text { Bone-hematite- } \\
\text { tempered }\end{array}$ & $\mathrm{N}$ \\
\hline Plain & 6 & - & - & 6 \\
Utility & 9 & - & - & 9 \\
Fine & 2 & 1 & 1 & 4 \\
\hline Totals & 17 & 1 & & 19 \\
\hline
\end{tabular}

The utility ware sherds in the assemblage are from brushed, brushed-incised, incised, incisedpunctated (Figure 3a), and punctated decorative elements (Table 4). The one incised-punctated sherd is likely from a Pennington Punctated-Incised vessel with a cane punctated-filled triangular incised zone (see Suhm and Jelks 1962:Plate 61).

Two of the fine ware engraved sherds from the Emerald Post Farm site are from Barkman Engraved carinated bowls (see Figure 3c-d), and another sherd with concentric circles and curvilinear hatched and cross-hatched zones may be from a Hatchel Engraved vessel (see Figure 3e). The one grog-bonetempered sherd in the collection is from a carinated bowl with a curvilinear hatched zone and closelyspaced curvilinear engraved lines (see Figure $3 b$ ).

The principal ancestral Caddo settlement of the site took place during the early part of the Texarkana phase, from ca. A.D. 1400-1500, as indicated by the Barkman Engraved and likely Hatchel Engraved sherds as well as the sherds from vessels with brushed decorative elements. An earlier occupation during the Early Caddo period (ca. A.D. 1000-1200) is marked by the Pennington Punctated-Incised body sherd, and likely also by the sherds with incised decorative elements. 


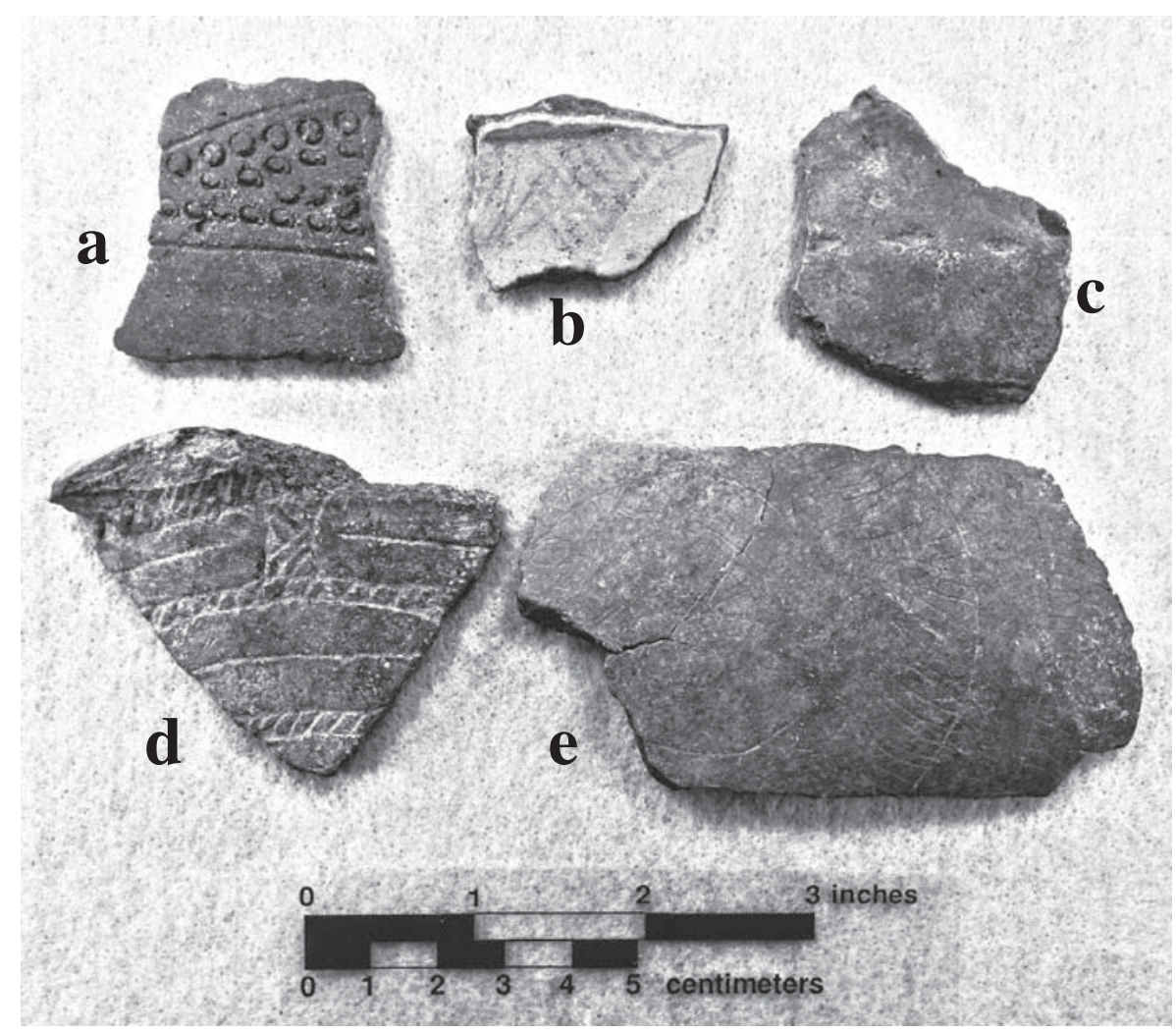

Figure 3. Selected decorated sherds from the Emerald Post Farm site: a, incisedpunctated; b, d-e, engraved; c, engraved-punctated.

Table 4. Decorative methods and elements in the utility ware and fine ware sherds from the Emerald Post Farm site assemblage.

\section{Utility Ware}

\section{Brushed}

parallel brushed

\section{Brushed-Incised}

parallel brushed-incised marks and lines

\section{Incised}

diagonal opposed incised lines

horizontal incised lines

horizontal-diagonal incised lines

parallel incised lines

\section{Incised-Punctated}

triangular incised zone filled with rows of cane punctations

\section{Punctated}


Table 4. Decorative methods and elements in the utility ware and fine ware sherds from the Emerald Post Farm site assemblage, cont.

\begin{tabular}{|c|c|c|c|}
\hline Decorative method and element & Rim & Body & $\mathrm{N}$ \\
\hline \multicolumn{4}{|l|}{ Fine Ware } \\
\hline \multicolumn{4}{|l|}{ Engraved } \\
\hline $\begin{array}{l}\text { concentric circles el. and curvilinear hatched and } \\
\text { cross-hatched zones }\end{array}$ & - & 1 & 1 \\
\hline curvilinear hatched zone and curvilinear engraved lines & - & 1 & 1 \\
\hline $\begin{array}{l}\text { interlocking hatched zones, horizontal lines, and } \\
\text { narrow hatched zone }\end{array}$ & 1 & - & 1 \\
\hline \multirow{2}{*}{$\begin{array}{l}\text { Engraved-Punctated } \\
\text { cross-hatched engraved zone and row of excised } \\
\text { punctations }\end{array}$} & & & \\
\hline & - & 1 & 1 \\
\hline Totals & 3 & 10 & 13 \\
\hline
\end{tabular}

\section{Coker Place (41CS1)}

The Coker Place is a Middle Caddo period (ca. A.D. 1200-1400) settlement with at least one constructed earthen mound and associated 5-6 acre village on the Sulphur River in the lower part of the basin. Archaeological investigations by the University of Texas archaeologists at the site in 1932 documented burned structures in one mound, along with the recovery of a substantial ceramic vessel sherd assemblage (Jackson 1932; Perttula 2015). A second apparent mound at the site was dug by looters in the 1990s, who uncovered a number of burial features and a Haley Engraved bottle, among other unknown funerary objects. The proportion of red-slipped sherds in the Middle Caddo period ceramic assemblage is notable (47 percent), as are the percentage of engraved sherds from red-slipped vessels (3.8 percent). Other decorative methods represented in the sherds include engraved (but not slipped) (6.3 percent), appliqued (6.9 percent) - probably from Pease Brushed-Incised vessels (Perttula et al. 1997:19) - incised (17.6 percent), punctated ( 8.2 percent), incised-punctated ( 0.6 percent), and brushed (10.1 percent). The one radiocarbon date from the Coker Place is A.D. 1300-1435 (2 sigma) (Perttula et al. 1997:17).

Pete Miroir also collected and donated the sherds from the Coker Place at the SNOMNH. These include plain, utility, and fine ware sherds from vessels made with grog ( 85 percent), grog-bone (9.9 percent), and grog-hematite (1.1 percent), as well as a few sherds from shell-tempered vessels (4.4 percent) (Table 5).

Table 5. Ceramic assemblage from the Coker Place (41CS1).

\begin{tabular}{lllcll}
\hline Ware & Grog & Grog-bone & Grog-hematite & Shell & N \\
\hline Plain & 17 & 5 & 1 & 1 & 24 \\
Utility & 24 & 2 & - & 3 & 29 \\
Fine & 36 & 2 & - & - & 38 \\
\hline Totals & 77 & 9 & 1 & 4 & 91 \\
\hline
\end{tabular}


Both utility ware and fine ware sherds are abundant in the Coker Place ceramic assemblage; 57 percent are from fine wares (see Table 5). Among the utility wares are sherds from appliqued (Figures 4a and 5c), brushed, brushed-appliqued, brushed-incised, incised (Figures $4 \mathrm{~d}$ and $7 \mathrm{a}$ ), incised-punctated (Figure 6), neck banded (Figure 4c), neck banded-appliqued (Figure 5b), punctated (Figure 5a), and trailed (Figure $4 \mathrm{~b}$ ) vessels (Table 6).

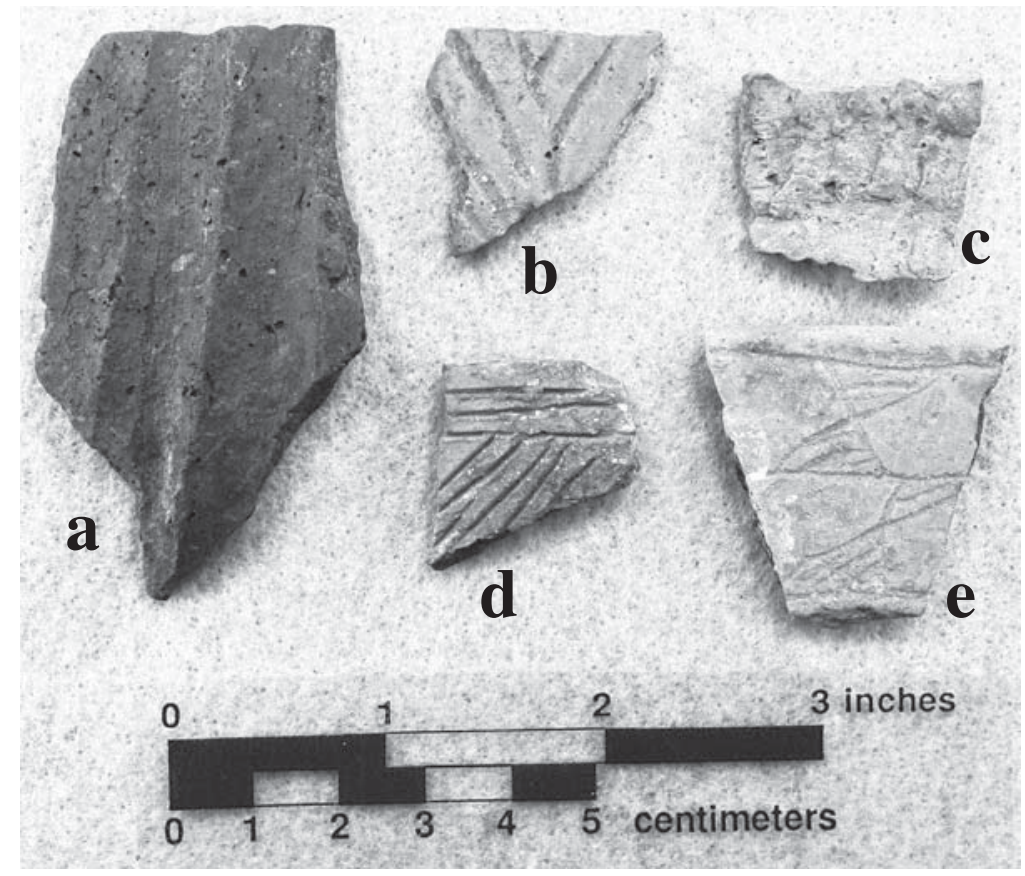

Figure 4. utility ware and fine ware sherds from the Coker Place site (41CS1): a, appliqued; b, trailed; c, neck banded; d, incised; e, engraved rim sherd.

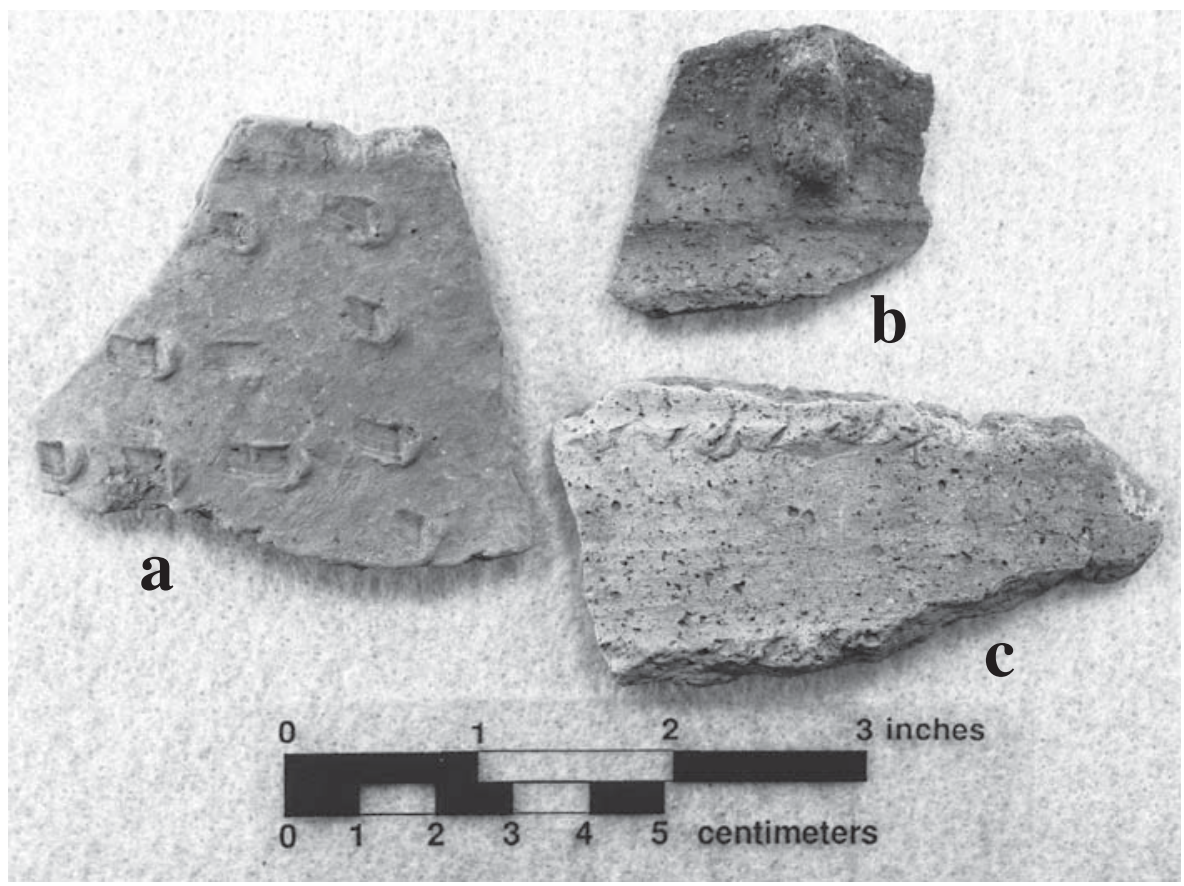

Figure 5. Utility ware sherds from the Coker Place site (41CS1): a, tool punctated; b-c, appliqued. 


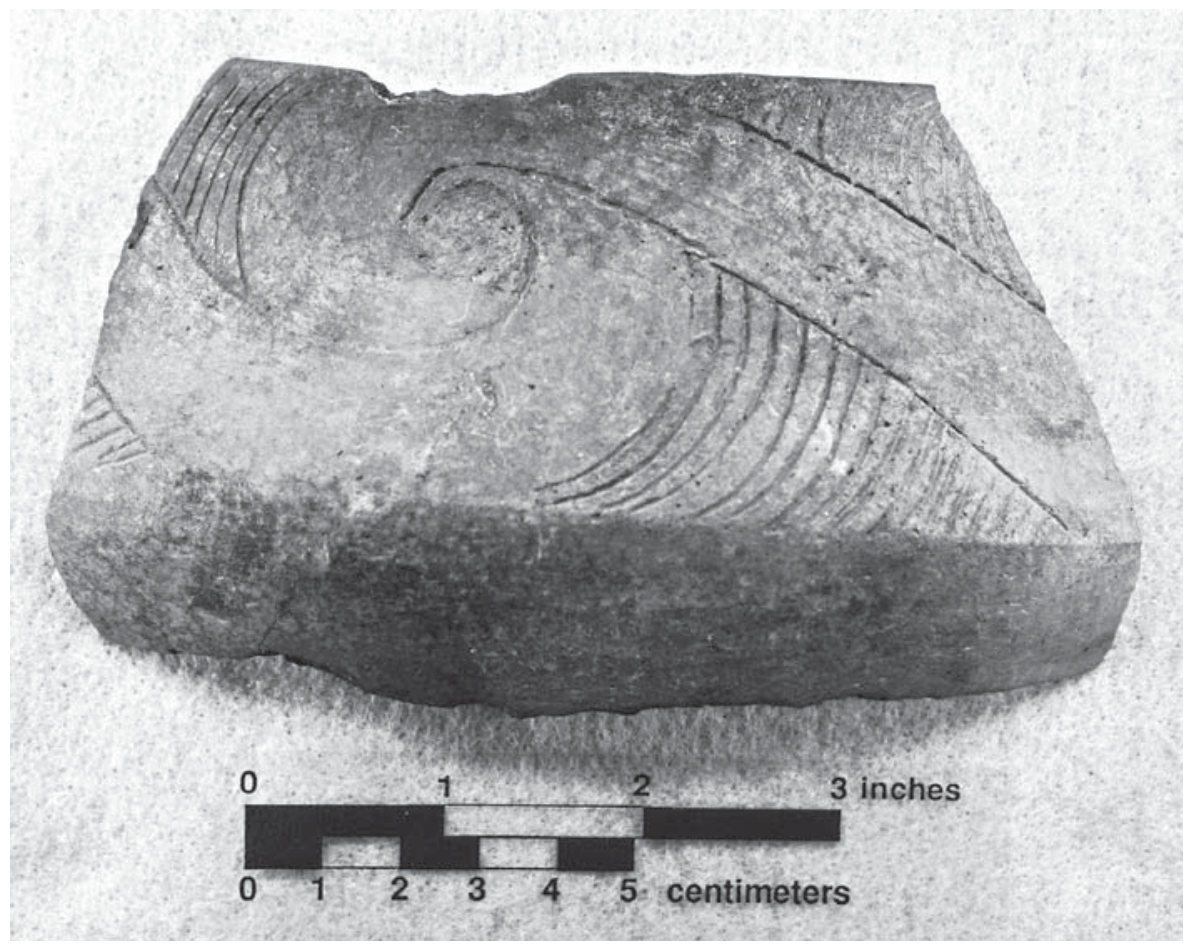

Figure 6. Crockett Curvilinear Incised carinated bowl rim sherd.

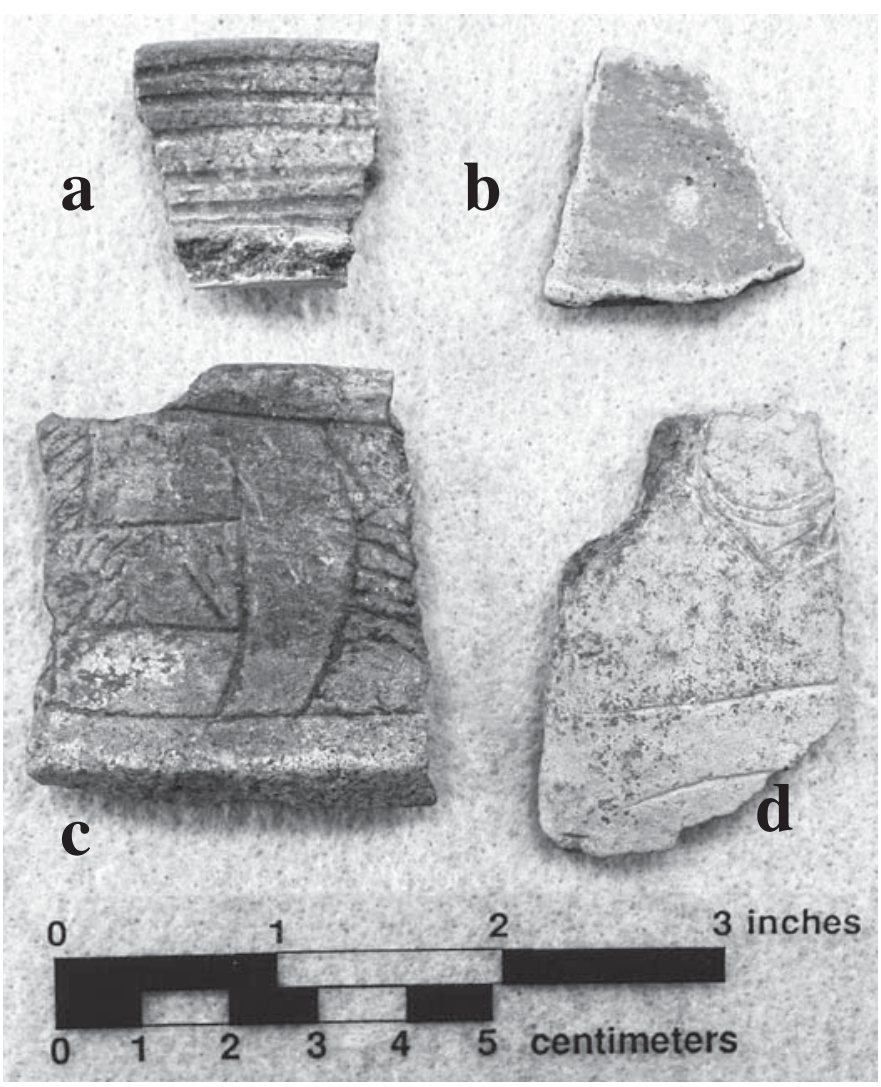

Figure 7. Utility ware and fine ware sherds from the Coker Place site (41CS1): a, incised rim sherd; b, red-slipped rim sherd; c-d, engraved carinated bowl sherds. 
Table 6. Decorative methods and elements in the utility ware and fine ware sherds from the Coker Place site (41CS1) assemblage.

\begin{tabular}{llll}
\hline Decorative method and element & Rim & Body & $N$ \\
\hline
\end{tabular}

\section{Utility Ware}

\section{Appliqued}

parallel appliqued fillets

parallel appliqued ridges

straight appliqued fillet

$\begin{array}{lll}- & 1 & 1 \\ - & 2 & 2 \\ - & 1 & 1\end{array}$

\section{Brushed}

opposed brushed marks

parallel brushed marks

1

2

Brushed-Appliqued

parallel brushed-parallel appliqued ridges

1

Brushed-Incised

horizontal brushed-incised marks and lines

1

Incised

curvilinear incised lines

closely-spaced horizontal incised lines

diagonal opposed incised lines

hatched triangle el. and hooked arms that meet at an excised circle el.

horizontal incised lines

parallel incised lines

Incised-Punctated

horizontal incised lines-fingernail punctated row beneath the lip

horizontal incised line-tool punctated rows

Neck Banded

parallel neck banded rows

-

$-$

1

$-2$

1

1

$-$

(1)

1

1

Neck Banded-Appliqued

horizontal neck bands and appliqued lug at the lip

1

1

Punctated

tool punctated rows

2

\section{Trailed}

opposed curvilinear trailed lines

\section{Fine Ware}

\section{Engraved}

cross-hatched engraved lines

curvilinear lines

curvilinear hatched triangle el. 
Table 6. Decorative methods and elements in the utility ware and fine ware sherds from the Coker Place site (41CS1) assemblage, cont.

\begin{tabular}{|c|c|c|c|}
\hline Decorative method and element & $\operatorname{Rim}$ & Body & $\mathrm{N}$ \\
\hline curvilinear hatched scroll fill zone & - & 1 & 1 \\
\hline hatched triangle el. and diagonal engraved lines & - & 1 & 1 \\
\hline horizontal engraved lines & 1 & - & 1 \\
\hline $\begin{array}{l}\text { horizontal-curvilinear engraved lines, hatched triangle } \\
\text { el. and hatched zones }\end{array}$ & 1 & - & 1 \\
\hline horizontal-vertical engraved lines & - & 1 & 1 \\
\hline $\begin{array}{l}\text { horizontal engraved line-vertical excised column- } \\
\text { triangle el. }\end{array}$ & $1^{*}$ & - & 1 \\
\hline horizontal hatched engraved zone & - & 1 & 1 \\
\hline opposed engraved lines & - & 1 & 1 \\
\hline stacked hatched triangle el. & 1 & - & 1 \\
\hline \multicolumn{4}{|l|}{ Engraved-Punctated } \\
\hline $\begin{array}{l}\text { horizontal engraved lines with excised punctations } \\
\text { between the lines }\end{array}$ & 1 & - & 1 \\
\hline \multicolumn{4}{|l|}{ Engraved-Red-Slipped } \\
\hline horizontal engraved line-int./ext. red-slipped & 1 & - & 1 \\
\hline \multicolumn{4}{|l|}{ Red-Slipped } \\
\hline ext. red-slipped & - & 5 & 5 \\
\hline int./ext. red-slipped & 1 & 18 & 19 \\
\hline Totals & 15 & 52 & 67 \\
\hline
\end{tabular}

*with a white clay pigment

The earliest Caddo ceramics at the Coker Place include sherds with horizontal incised lines (Davis Incised, see Figure 7a) and a rim sherd from a Crockett Curvilinear Incised carinated bowl (see Figure 6; see also Suhm and Jelks 1962:Plates 16 and 17). These are evidence of the Caddo use of the site in the Early Caddo period (ca. A.D. 1000-1200).

The principal Caddo settlement at the Coker Place took place during the Middle Caddo period, as mentioned above. The best evidence for this period of settlement is the high proportion of red-slipped rim and body sherds (see Figure 7b) - probably from Sanders Slipped vessels - as such sherds account for 36 percent of all the decorated sherds in the assemblage, and account for 66 percent of the fine ware sherds (including one rim sherd with a horizontal engraved line as well as slipped surfaces, (see Table 6). Other engraved sherds in this component includes a rim with stacked hatched triangles (see Figure 4e) and another rim sherd from a carinated bowl with stacked hatched triangles, diagonal hatched zones, and curvilinear and horizontal engraved lines (see Figure 7c). A second carinated bowl sherd has diagonal engraved lines and a curvilinear hatched triangle element (see Figure 7d).

The four shell-tempered sherds in the Coker Place assemblage include a plain body sherd and three utility ware sherds. One has a straight appliqued fillet (see Figure 5c), a second body sherd has parallel appliqued ridges (see Figure 4a), and another is a Nash Neck Banded rim sherd with an appliqued lug 
at the lip (see Figure 5b). These sherds are from utility ware vessels that were manufactured by Late Caddo period McCurtain phase Caddo potters in the mid-Red River basin, and traded/exchanged with the Texarkana phase settlement on the lower Sulphur River, where shell-tempered ceramics were very common. Also part of this component is a grog-tempered Foster Trailed-Incised body sherd (see Figure 4b); such vessels were made after ca. A.D. 1500 in Texarkana phase contexts.

In addition to the ceramic vessel sherds, two bone-tempered long-stemmed Red River pipe stems are in the collection. Their stem diameters range from $11.4 \mathrm{~mm}$ to $13.4 \mathrm{~mm}$, both probably from the Haley variety of the Red River pipe (Hoffman 1967:10).

\section{Ware Acres Site (41GG31)}

The ceramic sherds from the Ware Acres site came from midden excavations led by Buddy Jones in the early 1960s. This area, known as Area C (Perttula et al. 2013), was on an alluvial terrace of Grace Creek, a southward-flowing tributary to the Sabine River. Area C was located on the southern part of the terrace, and the archaeological deposits extended to the base of the terrace slope. The midden extended to ca. $76 \mathrm{~cm}$ bs, and it contained an abundance of ceramic sherds, animal bone, and a few lithic artifacts. Jones (1968:17) excavated a 4.6 × $6.1 \mathrm{~m}$ area in the southern part of Area C, and recovered over 15,000 ceramic sherds, including more than 2,500 rim sherds, from Ripley Engraved, Taylor Engraved, Wilder Engraved, Bullard Brushed, Karnack Brushed-Incised, and Harleton Appliqued vessels. Jones (1968:1718) also noted that there were remnants of house structures - marked by "dark ash colored areas" - in Area $\mathrm{C}$ that were graded away in modern house construction on the crest of the terrace, upslope from the thickest part of the midden deposits. These deposits likely date to after ca. A.D. 1600 because of the common occurrence of sherds from Ripley Engraved, var. McKinney, Simms Engraved, and Taylor Engraved vessels in the assemblage.

There are 41 ceramic vessel sherds in the SNOMNH assemblage from the Ware Acre site, including 36 decorated sherds (Table 7). The sherds are almost all from grog-tempered vessels ( 92.7 percent); the other sherds are plain rims from grog-bone-tempered vessels (Figure 8d-e).

Table 7. Ceramic assemblage from the Ware Acres site (41GG31).

\begin{tabular}{lccc}
\hline Ware & Grog-tempered & Grog-bone-tempered & N \\
\hline Plain & 3 & 2 & 5 \\
Utility & 15 & - & 15 \\
Fine & 20 & 1 & 21 \\
\hline Totals & 38 & 3 & 41 \\
\hline
\end{tabular}

The utility wares in this Ware Acres collection are dominated by brushed (see Figure 8a-b), brushedincised, and brushed-punctated body sherds from Bullard Brushed vessels (Table 8). The only other utility ware sherd is a body sherd with rows of linear tool punctations. 


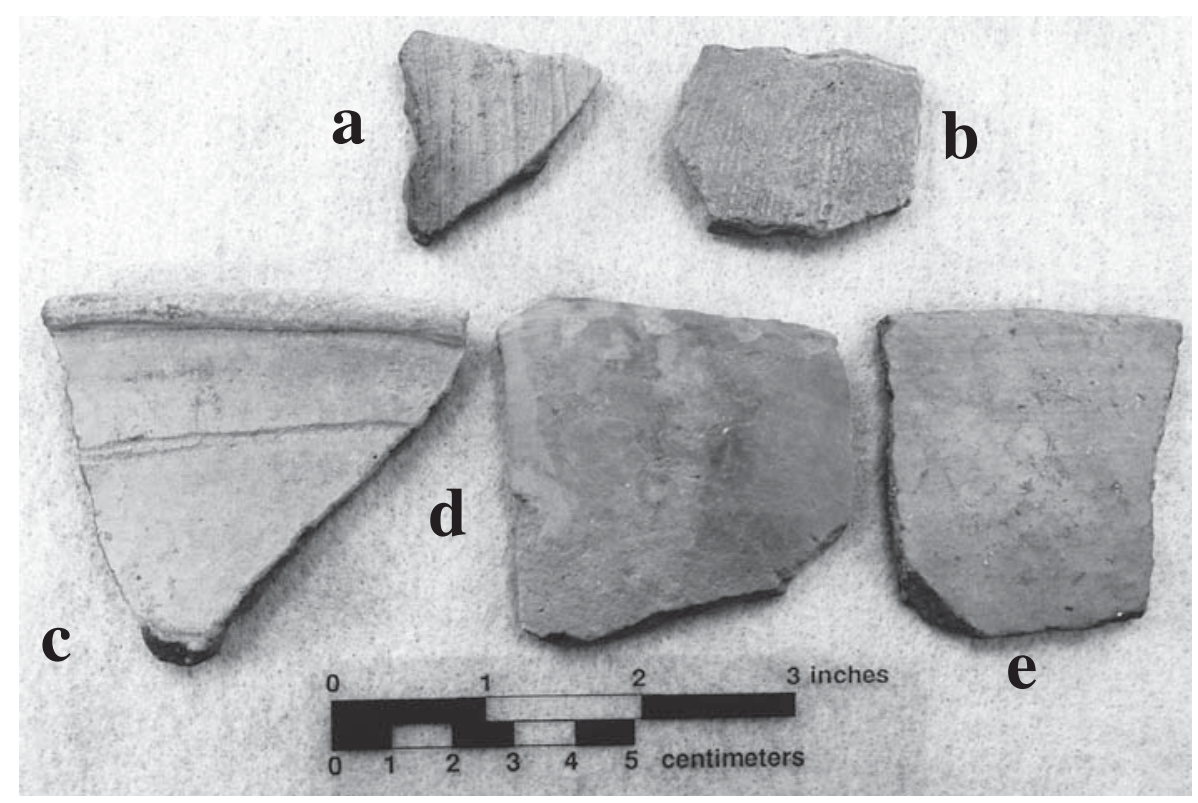

Figure 8. Plain ware, utility ware, and fine ware sherds from the Ware Acre site (41GG31): a-b, brushed; c, horizontal engraved; d-e, plain rim sherds.

Table 8. Decorative methods and elements in the utility ware and fine ware sherds from the Ware Acres site (41GG31) assemblage.

Decorative method and element

Rim

Body

$\mathrm{N}$

\section{Utility Ware}

\section{Brushed}

horizontal brushed marks

opposed brushed marks

parallel brushed marks

$\begin{array}{lll}- & 1 & 1 \\ - & 2 & 2 \\ - & 8 & 8\end{array}$

\section{Brushed-Incised}

parallel brushed-incised marks and lines

\section{Brushed-Punctated}

parallel brushed marks-tool punctated row through the

brushing

\section{Punctated}

linear tool punctated rows

Fine Ware

\section{Engraved}

continuous scroll motif; ticked scroll line

engraved diamond el.

excised scroll fill zone

hooked arm el.

horizontal engraved lines

horizontal engraved lines and vertical hatched zones 
Table 8. Decorative methods and elements in the utility ware and fine ware sherds from the Ware Acres site (41GG31) assemblage, cont.

\begin{tabular}{llll}
\hline Decorative method and element & Rim & Body & N \\
\hline horizontal engraved line and vertical scroll divider & - & 2 & 2 \\
horizontal engraved line on int. surface at carina & - & 1 & 1 \\
horizontal-diagonal-curvilinear lines & 1 & - & 1 \\
interlocking horizontal scroll motif & $2 *$ & - & 2 \\
alternate nested triangle motif & 1 & - & 1 \\
slanting scroll motif & 2 & - & 2 \\
scroll and circle motif & $1 *$ & - & 1 \\
Excised Punctations & & & 1 \\
row of excised punctations at carina & - & 1 & 1 \\
Red-Slipped & & & 36 \\
int.lext. red-slipped & - & 1 & \\
\hline Totals & 12 & 24 & \\
\hline
\end{tabular}

*white pigment in engraved lines on one sherd

The fine ware sherds in the Ware Acre assemblage are from compound bowls (see Figure 8c) and carinated bowls that have engraved, excised punctations, and red-slipped decorative elements (see Table 8). Most of the engraved sherds are from several different varieties of Ripley Engraved (Figures 9a-d, 10a-d, and 11c) (see Perttula et al. 2012:Figure 5; Fields et al. 2014:Table 8.6), but there are several Taylor Engraved, var. Taylor carinated bowl rim sherds in the assemblage (Figure 11a-b, d-e).

The Taylor Engraved sherds and the Ripley Engraved, var. McKinney sherds suggest that these sherds from the Ware Acre site are from a Late Caddo period Titus phase component dating between ca. A.D. 1550-1680. The other Ripley Engraved varieties may date to both early (ca. A.D. 1430-1550) and late intervals of the Titus phase, with var. Carpenter and var. Gandy most commonly noted in early Titus phase sites and var. Williams dating to the late Titus phase (Perttula 2017b:Table 21).

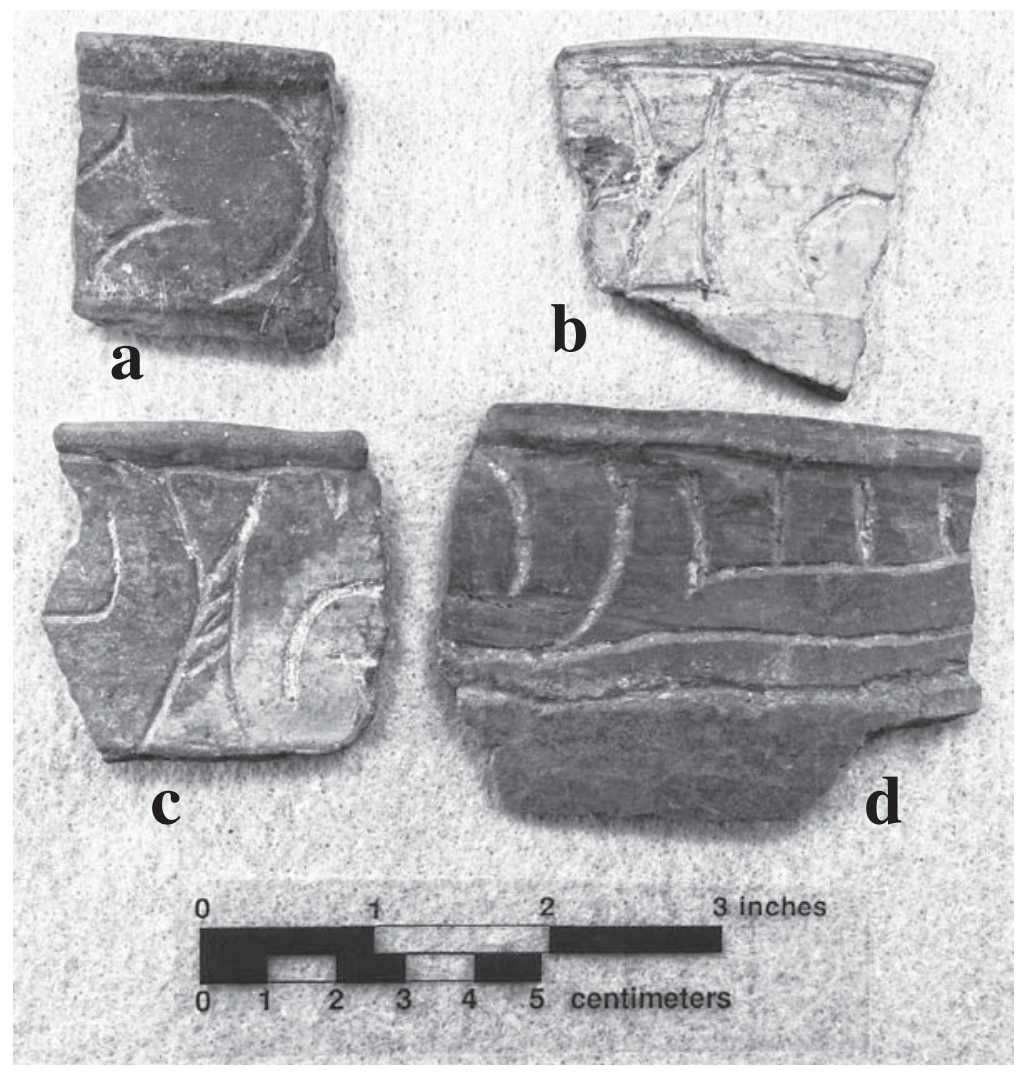

Figure 9. Ripley Engraved rim sherds from the Ware Acre site (41GG31): a, var. McKinney; b-c, var. Pilgrims; d, var. Gandy. 


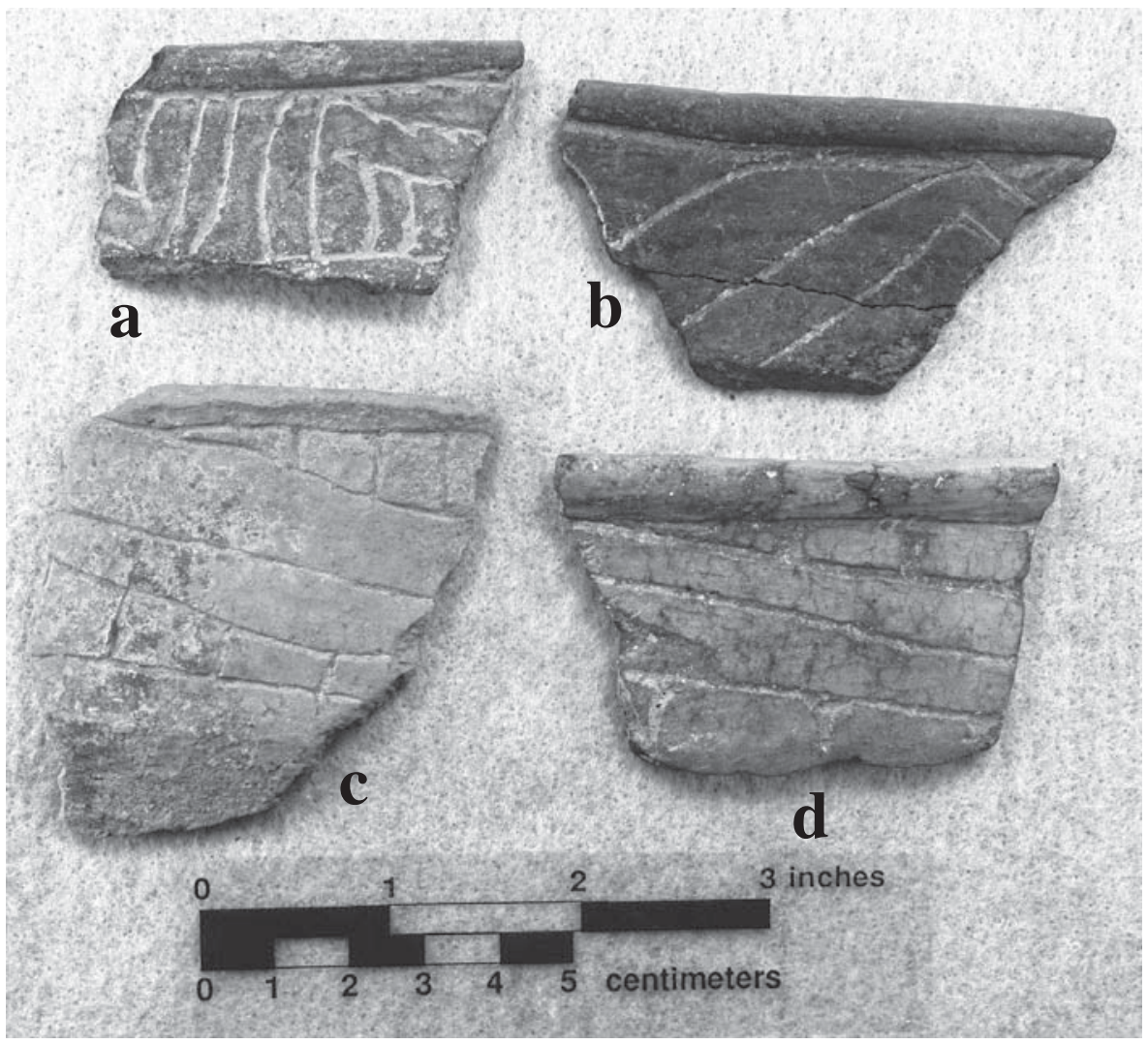

Figure 10. Other Ripley Engraved rim sherds from the Ware Acres site (41GG31): a, var. Gandy; b, var. Williams; c-d, var. Carpenter.

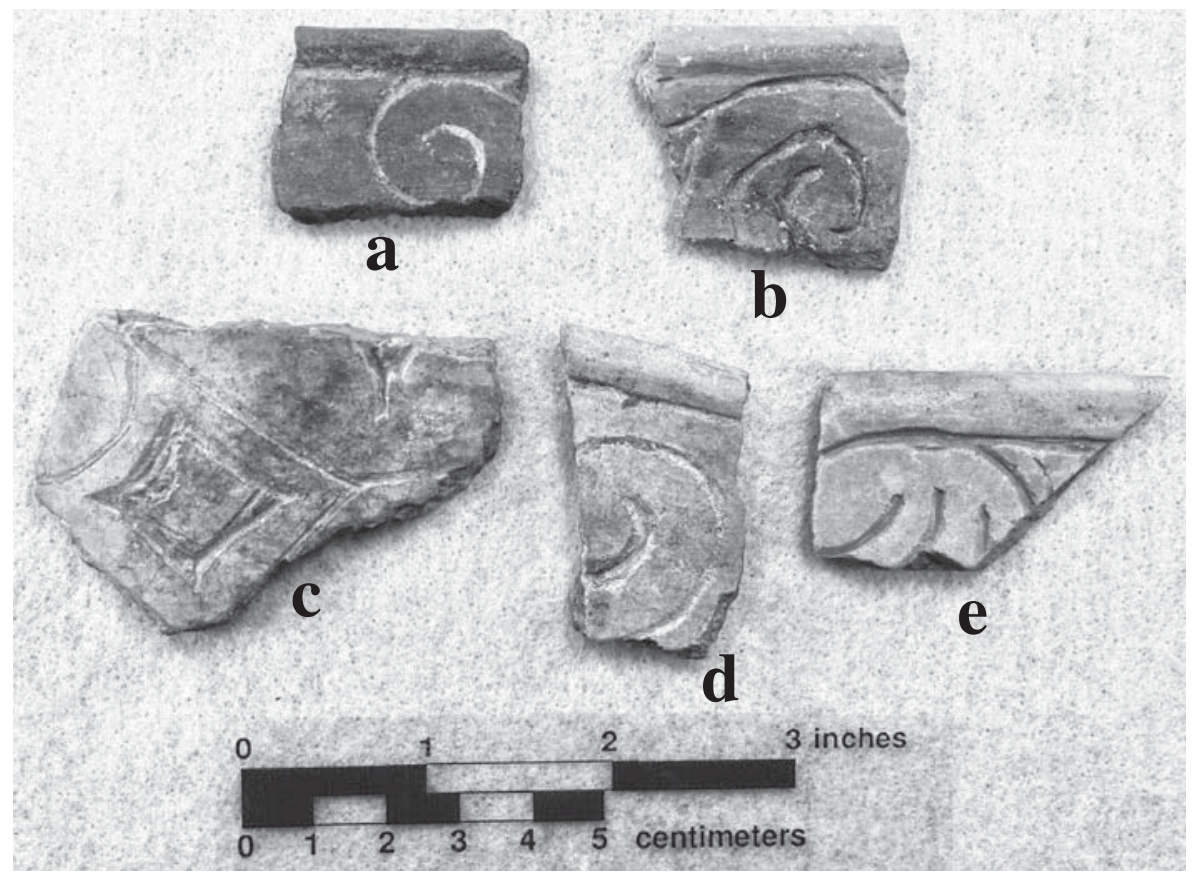

Figure 11. Ripley Engraved and Taylor Engraved sherds from the Ware Acres site (41GG31): a-b, d-e, Taylor Engraved, var. Taylor; c, Ripley Engraved, var. McKinney. 


\section{Sanders Site (41LR2)}

The ceramic vessel sherds in this assemblage from the Sanders site were donated to the SNOMNH in July 1976 by R. K. Harris, a well-known avocational archaeologist from Dallas, Texas. The assemblage includes 33 sherds from plain ware, utility ware, and fine ware vessels (Table 9). The sherds are from vessels tempered with grog ( 88 percent) and grog-bone (12 percent) inclusions. The assemblage is about equally divided between utility wares and fine wares. As discussed below, these sherds are from the Middle Caddo period Sanders phase component at the site (Perttula et al. 2016, 2017).

Table 9. Ceramic assemblage from the Sanders site (41LR2).

\begin{tabular}{lccc}
\hline Ware & Grog-tempered & Grog-bone-tempered & $\mathrm{N}$ \\
\hline Plain & 4 & - & 4 \\
Utility & 13 & 1 & 14 \\
Fine & 12 & 3 & 15 \\
\hline Totals & 29 & 4 & 33 \\
\hline
\end{tabular}

The utility ware sherds in this collection from the Sanders site include rim and body sherds from incised, incised-punctated, and punctated vessels (Table 10). These include sherds from Canton Incised vessels (Figures 12 and 13e-f) and body sherds from Monkstown Fingernail Impressed jars (Figure 13c).

Table 10. Decorative methods and elements in the utility ware and fine ware sherds from the Sanders site (41LR2) assemblage.

\begin{tabular}{llll}
\hline Decorative method and element & Rim & Body & N
\end{tabular}

\section{Utility Ware}

\section{Incised}

diagonal incised lines

diagonal and cross-hatched incised lines

diagonal opposed incised lines

opposed incised lines

parallel incised lines

vertical incised lines

$\begin{array}{lll}4 & - & 4 \\ 1 & - & 1 \\ 1 & 1 & 2 \\ - & 1 & 1 \\ - & 1 & 1 \\ 1 & - & 1\end{array}$

\section{Incised-Punctated}

diagonal incised lines-triangle zone filled with

circular punctations

diagonal opposed incised lines-triangle zone filled

with tool punctations

Punctated

fingernail punctated rows

\section{Fine Ware}

\section{Engraved}

engraved scrolls and hatched lines

vertical engraved lines 
Table 10. Decorative methods and elements in the utility ware and fine ware sherds from the Sanders site (41LR2) assemblage, cont.

\begin{tabular}{llll}
\hline Decorative method and element & Rim & Body & N \\
\hline Red-Slipped & & & \\
$\begin{array}{l}\text { int./ext. red-slipped } \\
\text { ext. red-slipped }\end{array}$ & $8^{*}$ & 4 & 12 \\
\hline Totals & - & 1 & 11 \\
\hline
\end{tabular}

*one rim sherd is an effigy head

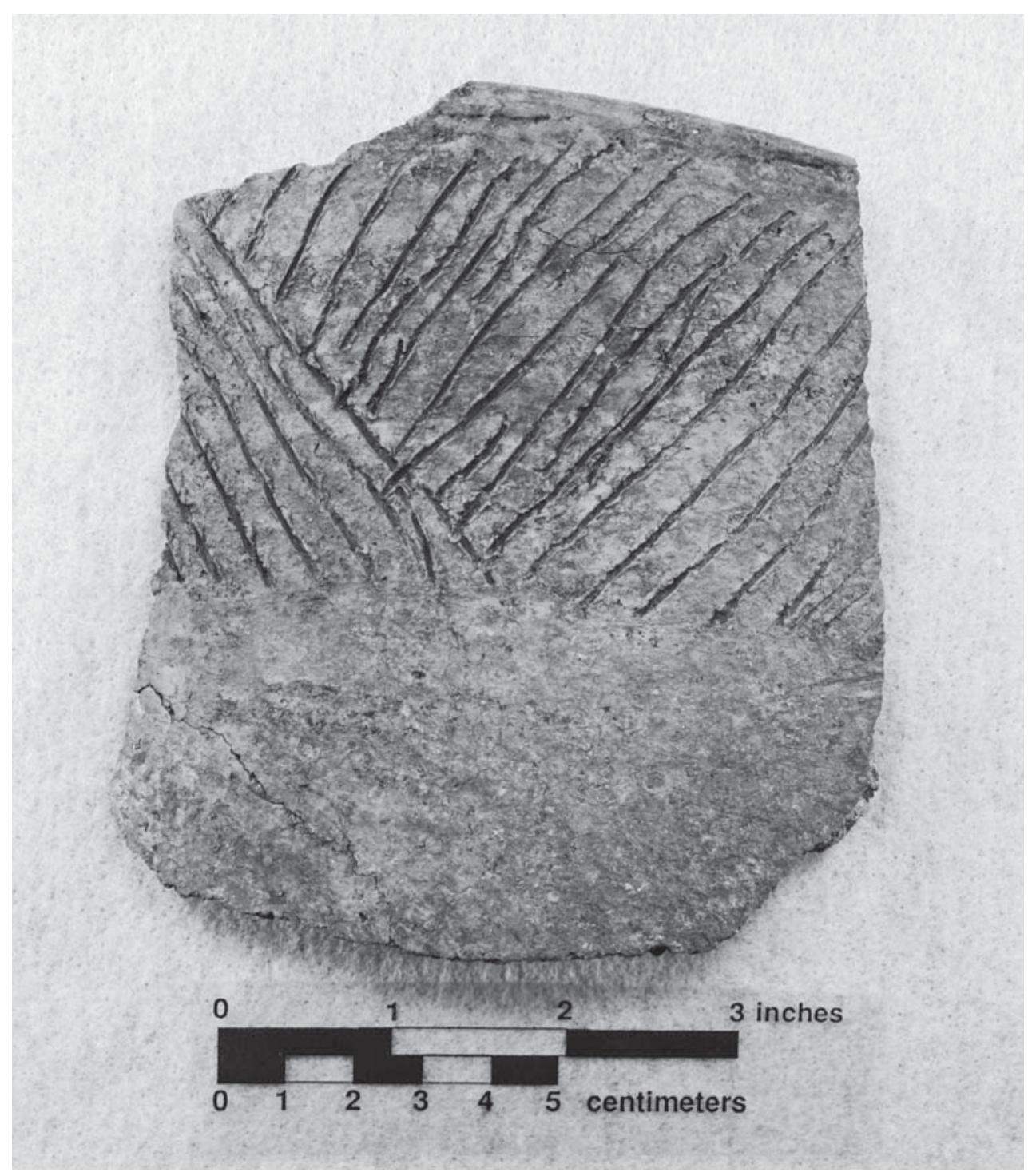

Figure 12. Canton Incised rim sherd from the Sanders site (41LR2). 


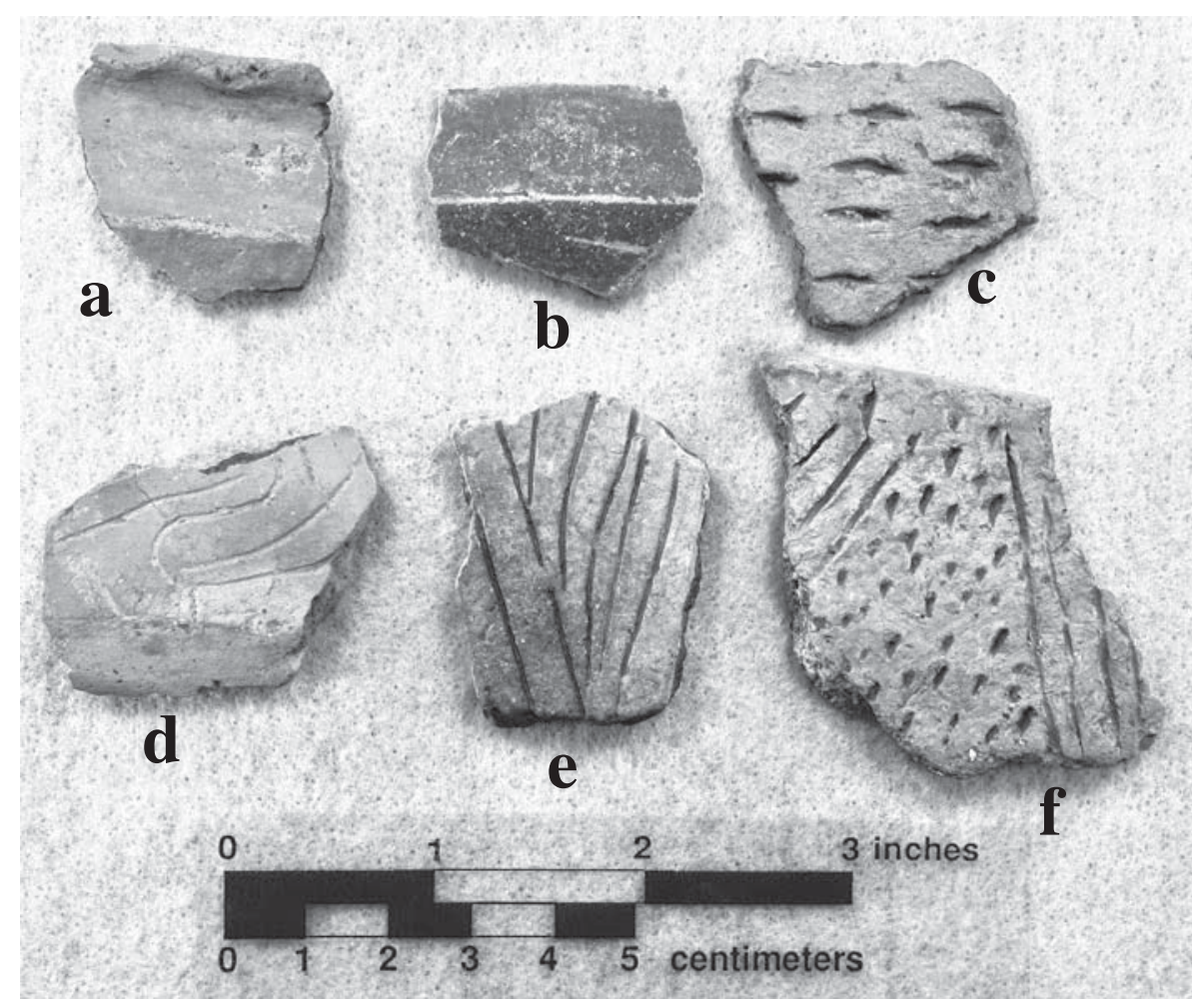

Figure 13. Fine ware and utility ware sherds from the Sanders site (41LR2): a-b, Sanders Slipped; c, Monkstown Fingernail Impressed; d, engraved carinated bowl sherd; e-f, Canton Incised.

The fine wares in the Sanders site collection include one Sanders Engraved rim sherd with vertical engraved lines (see Table 10), and a sherd from a carinated bowl with engraved curvilinear scrolls and hatched lines (see Figure 13d). However, almost 87 percent of the fine ware sherds are rim and body sherds from Sanders Slipped carinated bowls (see Figure 13a-b) and bottles.

The most distinctive of the sherds from this Sanders site collection is a clay effigy head from an effigy bowl (Figure 14a-b). The effigy head has a nose and ears, and may represent a canid. The effigy head and the vessel have a red slip on both vessel surfaces.

In addition to the ceramic vessel sherds, there is a single Middle Caddo period grog-tempered var. Haley long-stemmed Red River pipe stem sherd in the collection (see Hoffman 1967). The stem diameter is $12.2 \mathrm{~mm}$ and the hole diameter is $4.1 \mathrm{~mm}$.

\section{Sam Kaufman (41RR16)}

This sherd collection from the Sam Kaufman site, a well-known ancestral Caddo multiple mound center and village on Mound Prairie on the Red River (Perttula 2008; Skinner et al. 1969), was donated to the SNOMNH by Frank de la Mater. There are also a few chipped and ground stone tools in the collection (see below).

The plain ware, utility ware, and fine ware sherds are primarily from shell-tempered vessels (72 percent) made by Late Caddo period McCurtain phase potters, but the remainder of the sherds are from grog (25 percent)- and grog-bone (2.9 percent)-tempered vessels that are part of the Middle Caddo period Mound Prairie phase occupation of the settlement (see Perttula 2008). 

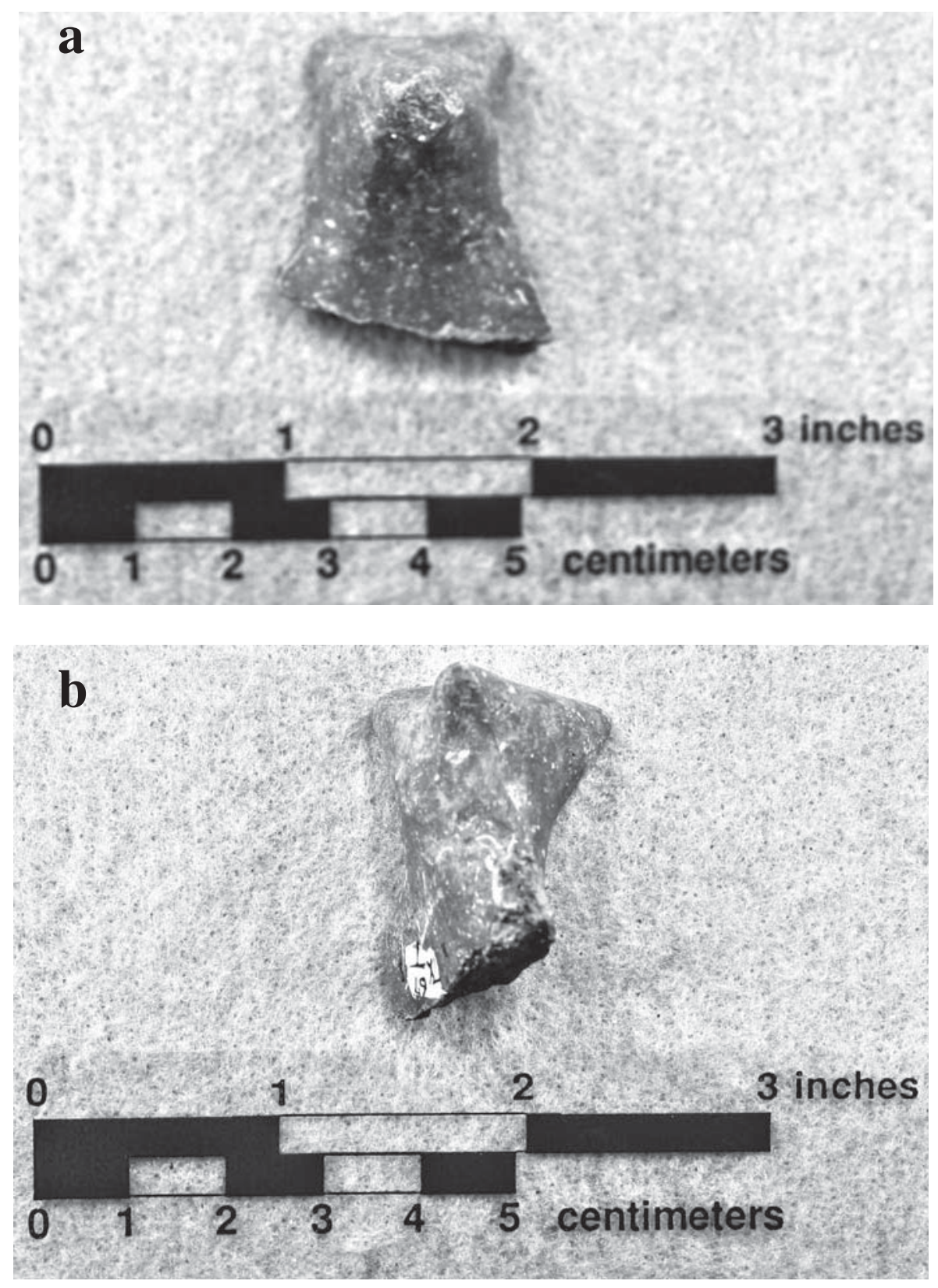

Figure 14. Ceramic effigy head sherd: a, front view; b, side view.

Table 11. Ceramic vessel sherd assemblage from the Sam Kaufman site (41RR16).

\begin{tabular}{lcccc}
\hline Ware & Grog-tempered & Grog-bone-tempered & Shell-tempered & N \\
\hline Plain & 60 & 7 & 182 & 249 \\
Utility & 2 & 1 & 13 & 16 \\
Fine & 16 & 1 & 30 & 47 \\
\hline Totals & 78 & 9 & 225 & 312 \\
\hline
\end{tabular}


The shell-tempered wares include a number of neck banded body sherds from Nash Neck Banded jars (Table 12 and Figure 15a-b). The sherd with the vertical appliqued fillet and tool punctated row may also be from a Nash Neck Banded vessel (see Suhm and Jelks 1962:111 and Plate 56). The incised and punctated sherds are likely from Emory Punctated-Incised vessels; this type was defined in print by Story et al. (1967:136-138). The type occurs in both prehistoric and historic Caddo contexts, based primarily on a large assemblage of Late and early Historic Caddo McCurtain phase vessels from sites on the Red River in East Texas and Southeast Oklahoma. According to Story et al. (1967:137), Emory PunctatedIncised occurs as jars tempered with sand, sand-shell, sand and grog, or sand and bone. "Some vessels have only punctations arranged into one to four rows around the vessel, usually just below the lip. If brushing is present, it may occur almost anywhere on the vessel, from the lip to the base. If incising is present, it usually consists of straight to slightly curved lines extending from below the rim to the base or to about the middle of the body. Punctations are often combined with either incising or brushing" (Story et al. 1967:137). Red River varieties of Emory Punctated-Incised, commonly shell-tempered, also include appliqued elements on the vessel bodies as well as horizontal row of punctations on the rim.

Table 12. Decorative methods and elements in the utility ware and fine ware sherds from the Sam Kaufman site (41RR16) assemblage.

\begin{tabular}{llll}
\hline Decorative method and element & Rim & Body & N
\end{tabular}

Shell-tempered

$\underline{\text { Utility Ware }}$

Appliqued-Punctated

vertical appliqued fillet-tool punctated row

$-\quad 1$

Incised

parallel incised lines

$\begin{array}{ll}- & 1\end{array}$

Neck Banded

neck banded rows

$-$

8

8

Punctated

fingernail punctated row

tool punctated rows

$\begin{array}{ll}- & 1\end{array}$

1

Fine Ware

Engraved-Red-Slipped

horizontal engraved lines-int./ext. red-slipped

1

Red-Slipped

ext. red-slipped

int./ext. red-slipped

$\begin{array}{ll}- & 9\end{array}$

929

$\begin{array}{lll}1 & 19 & 20\end{array}$

Grog- and grog-bone tempered

\section{Utility Ware}

Incised-Punctated

horizontal incised line-adjacent tool punctated row

straight incised line-adjacent tool punctated rows

$\begin{array}{lll}- & 1 & 1 \\ - & 3 & 3\end{array}$


Table 12. Decorative methods and elements in the utility ware and fine ware sherds from the Sam Kaufman site (41RR16) assemblage, cont.

\begin{tabular}{llcc}
\hline Decorative method and element & Rim & Body & N \\
\hline $\begin{array}{l}\text { Punctated } \\
\text { tool punctated rows }\end{array}$ & 1 & - & 1 \\
Fine Ware & - & 1 & 1 \\
$\begin{array}{l}\text { Engraved } \\
\text { diagonal engraved lines }\end{array}$ & - & 1 & 1 \\
$\begin{array}{l}\text { Engraved-Red-Slipped } \\
\text { straight engraved line-int./ext. red-slipped }\end{array}$ & & & \\
$\begin{array}{l}\text { Red-Slipped } \\
\text { ext. red-slipped } \\
\text { int./ext. red-slipped }\end{array}$ & - & 5 & 5 \\
\hline \begin{tabular}{l} 
Totals \\
\hline
\end{tabular} & 1 & 9 & 63 \\
\hline
\end{tabular}

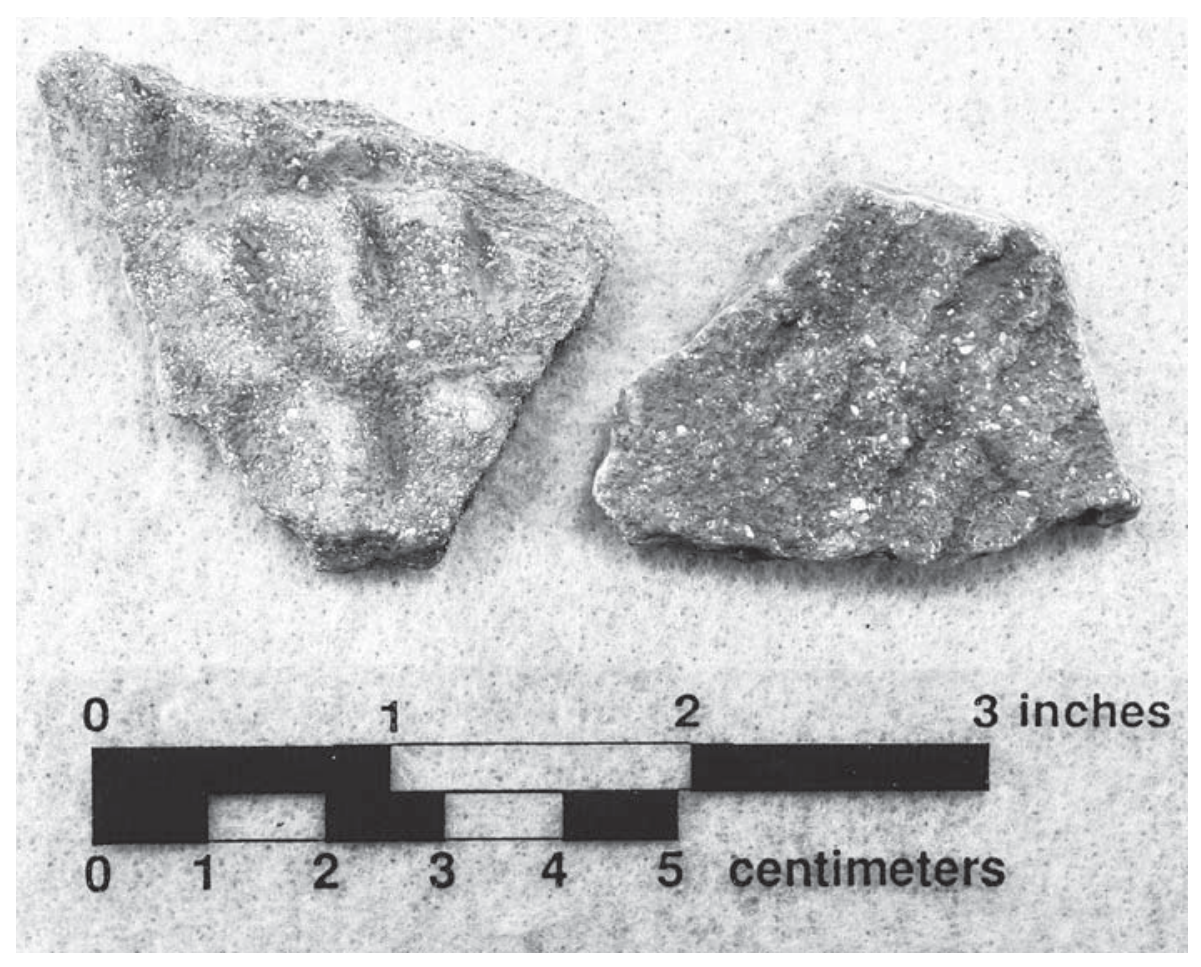

Figure 15. Shell-tempered Nash Neck Banded sherds from the Sam Kaufman site (41RR16). 
The shell-tempered fine ware sherds are mainly from red-slipped Clement Redware (see Flynn 1976) vessels along with one red-slipped rim with horizontal engraved lines. Red-slipped shell-tempered vessels are common in McCurtain phase sites in the mid-Red River basin, including sites in both East Texas and southeastern Oklahoma. The engraved rim may be from an effigy vessel given the placement of three horizontal engraved lines around the rim of the vessel.

The Mound Prairie phase ceramics from the Sam Kaufman site are dominated by Sanders Slipped rim and body sherds (see Table 12). There are also two body sherds from Sanders Engraved vessels - one of which is red-slipped - as well as four Canton Incised body sherds, and a rim with tool punctations (see Table 12).

The lithic artifacts in this Sam Kaufman collection includes two Woodland period Gary points made from red or dark grayish-brown Red River gravel chert. The two points have 14.9-17.0 mm stem widths, and range in thickness from 6.5-7.7 mm. Another tool is a brown jasper drill, along with a Late Caddo period triangular arrow point made from a heat-treated novaculite, probably also collected from Red River gravels. The last tool is the bit and body fragment of a greenstone or siliceous shale celt.

\section{Bentsen-Clark (41RR41)}

The collection of ceramic vessel sherds at the SNOMNH from the Bentsen-Clark site was collected and donated by R. King Harris. The Bentsen-Clark site, on the Red River, is a multicomponent ancestral Caddo settlement and cemetery (see Banks and Winters 1975). The assemblage includes only 21 sherds from grog-tempered (71 percent) and grog-bone-tempered (29 percent) vessels (Table 13). Most of the sherds are from utility and fine ware vessels. One plain ware rim has rim peaks (Figure 16e).

Table 13. Ceramic vessel sherd assemblage from the Bentsen-Clark site (41RR41).

\begin{tabular}{lccc}
\hline Ware & Grog-tempered & Grog-bone-tempered & N \\
\hline Plain & 4 & - & 4 \\
Utility & 7 & - & 7 \\
Fine & 4 & 6 & 10 \\
\hline Totals & 15 & 6 & 21 \\
\hline
\end{tabular}

The utility wares from the Bentsen-Clark site include four rim sherds from Davis Incised vessels and a body sherd from a Dunkin Incised vessel with horizontal incised lines and a vertical hatched zone (Table 14; see Suhm and Jelks 1962:Plates 18 and 19). The one incised-punctated sherd (Figure 17c) may be from a Crockett Curvilinear Incised vessel. Such utility ware types suggest that this ceramic assemblage from the Bentsen-Clark site is from the Early Caddo period occupation there; the fine ware sherds in the collection strengthen that suggestion (see below). 


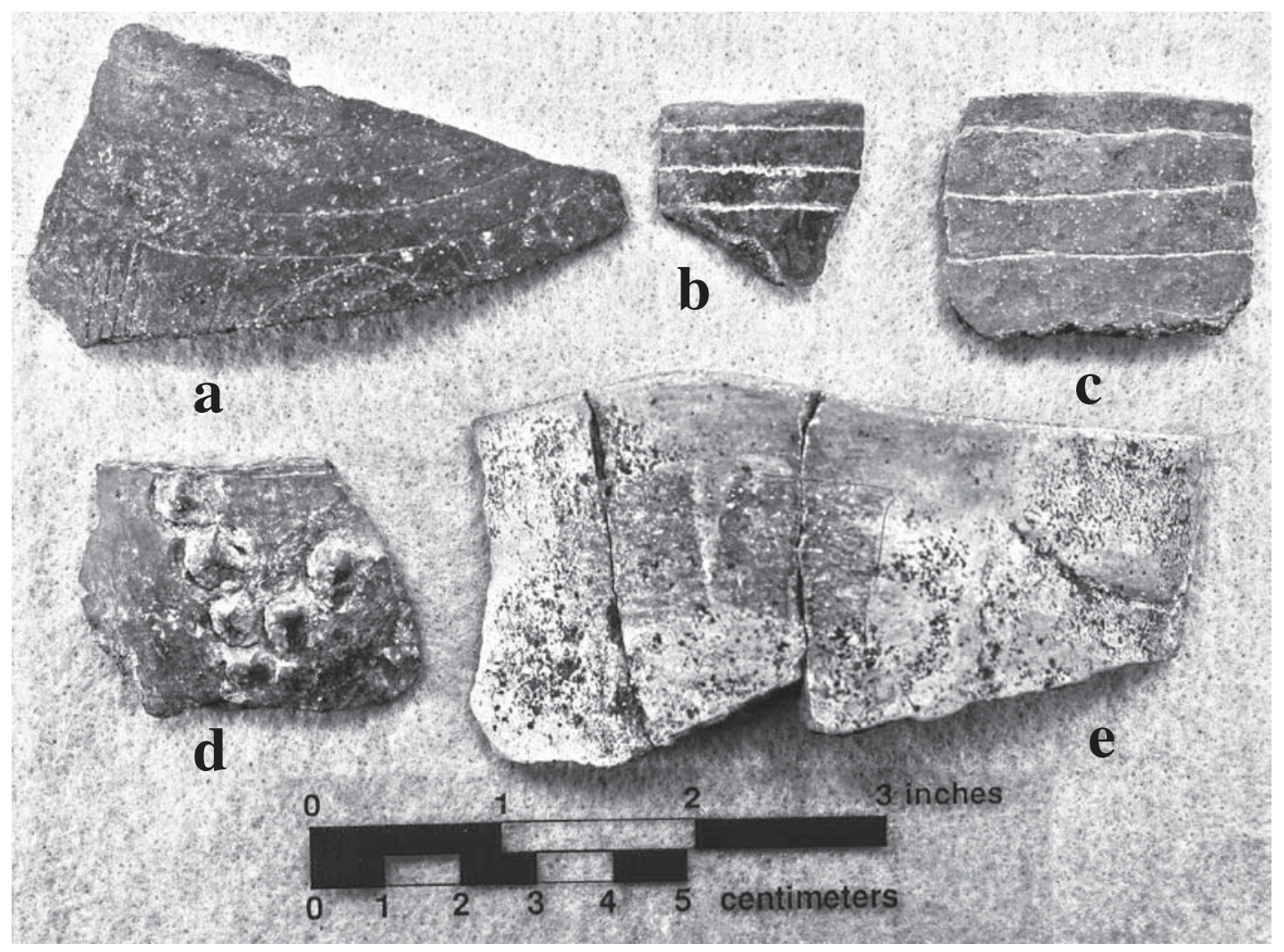

Figure 16. Plain ware, utility ware, and fine ware sherds from the Bentsen-Clark site (41RR41): a, Holly Fine Engraved; b-c, Hickory Engraved; d, appliqued-brushed body sherd; e, plain rim sherd with rim peak.

Table 14. Decorative methods and elements in the utility ware and fine ware sherds from the Bentsen-Clark site (41RR41) assemblage.

\begin{tabular}{llll}
\hline Decorative method and element & Rim & Body & $N$
\end{tabular}

\section{Utility Ware}

\section{Brushed-Appliqued}

parallel brushed areas- $\mathrm{V}$-shaped appliqued nodes

\section{Incised}

horizontal incised lines

horizontal incised lines and vertical hatched zone

$\begin{array}{lll} & & \\ 4 & - & 4 \\ - & 1 & 1 \\ - & & \\ & 1 & 1\end{array}$

\section{Incised-Punctated}

curvilinear incised zone with circular punctations

\section{Fine Ware}

\section{Engraved}

curvilinear engraved lines-sets of vertical linesconcentric circle el. (Holly Fine Engraved) curvilinear engraved lines-sets of vertical linescross-hatched zone (Spiro Engraved) 
Table 14. Decorative methods and elements in the utility ware and fine ware sherds from the Bentsen-Clark site (41RR41) assemblage, cont.

\begin{tabular}{llll}
\hline Decorative method and element & Rim & Body & N \\
\hline $\begin{array}{l}\text { horizontal engraved lines (Hickory Engraved) } \\
\text { horizontal and curvilinear engraved lines } \\
\text { horizontal and semi-circular engraved lines, excised } \\
\text { semi-circles and brackets (Holly Fine Engraved) } \\
\text { horizontal-vertical-diagonal engraved lines } \\
\begin{array}{l}\text { Spiro Engraved) } \\
\text { straight and concentric circular engraved lines }\end{array}\end{array} 2^{*}$ & 1 & - & 3 \\
$\begin{array}{l}\text { Engraved-Excised Punctations } \\
\text { opposed curvilinear engraved lines, excised zone, and } \\
\text { curvilinear zone with small excised punctations (Spiro } \\
\text { Engraved) }\end{array}$ & - & 1 & 1 \\
\hline \begin{tabular}{l} 
Totals \\
\hline
\end{tabular} & - & 1 & 1 \\
\hline
\end{tabular}

*one sherd with red pigment in engraved lines

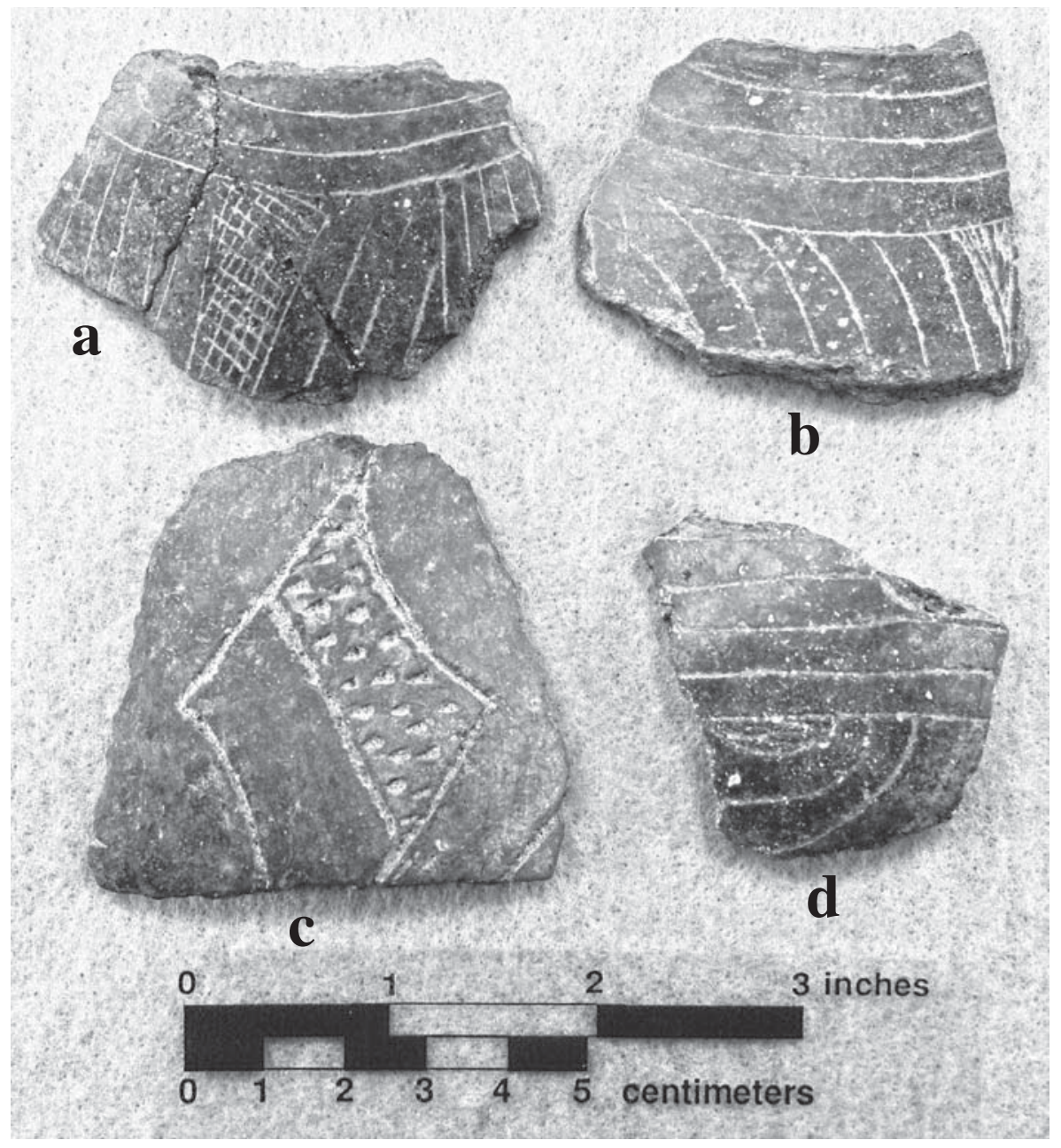

Figure 17. Utility ware and fine ware sherds from the Bentsen-Clark site: a-b, Spiro Engraved; c, Crockett Curvilinear Incised; d, Holly Fine Engraved. 
The fine ware sherds are from Hickory Engraved bottles (see Figure 16b-c), Holly Fine Engraved bottles (see Figures 16a and 17d), and Spiro Engraved bottles (see Figure 17a-b) (see Table 14). As a group, they well represent the Early Caddo period use of the Bentsen-Clark site, dating between ca. A.D. 1000-1200. Of the 61 ceramic vessels recovered from Feature 1 excavations at the site, 24 (including sherd groups from distinct vessels) are of the Spiro Engraved type, along with two Holly Fine Engraved bottles and carinated bowls, and two Hickory Engraved bottles (Banks and Winters 1975:37-44).

Several of the engraved sherds (30 percent) from Hickory Engraved and Spiro Engraved vessels in the collection have a red pigment rubbed in the engraved lines (see Table 14). The use of pigments is a common method of enhancing the decorative elements on Caddo vessels, and a red pigment was a common choice in Early and Middle Caddo sites in East Texas (Perttula 2017c:Table 4).

\section{Summary}

During the course of a recent documentation effort focusing on ancestral Caddo ceramic vessels in the George T. Wright collection at the Sam Noble Oklahoma Museum of Natural History (SNOMNH) from East Texas sites, we had the opportunity to document surface collections of ceramic vessel sherd assemblages in the SNOMNH collections from seven Caddo sites in Bowie, Cass, Gregg, Lamar, and Red River counties, some recorded and two others (both in Bowie County) not yet formally recorded. The recorded sites include the Coker Place (41CS1), Ware Acres (41GG31), Sanders (41LR2), Sam Kaufman (41RR16), and Bentsen-Clark (41RR41).

Relying on temper use documented in the vessel sherds and the decorative methods and elements present on the utility ware and fine ware vessel sherds in each assemblage, it is clear that the vessel sherds at the seven sites represent ancestral Caddo use in different parts of East Texas - from the Red River south to the Sabine River basin-from as early as ca. A.D. 1000 to as late as the $17^{\text {th }}$ century A.D. The principal Early Caddo period (ca. A.D. 1000-1200) component in the assemblages is at the BentsenClark site, but the Aiken Creek, Emerald Post, and Coker Place sites also have evidence that they were used as well during the Early Caddo period. Middle Caddo period (ca. A.D. 1200-1400) components are strongly represented at the Coker Place, Sanders, and Sam Kaufman sites; these components are best evidenced by grog-tempered and grog-tempered red-slipped sherds from Sanders Slipped vessels. The ceramic assemblages at the Aiken Creek, Emerald Post, Coker Place, Ware Acres, and Sam Kaufman sites also provide evidence of Late Caddo period (ca. A.D. 1400-1680) settlement in these locales. At the Aiken, Emerald Post, and Coker Place sites, the ceramic sherds are associated with Texarkana phase occupations dating between ca. A.D. 1400-1550. The Late Caddo period occupation at the Ware Acres site belongs to the latter part of the Titus phase, from ca. A.D. 1550-1680. The McCurtain phase occupation at the Sam Kaufman site is probably contemporaneous with the Titus phase settlement at the Ware Acres site.

\section{Acknowledgments}

We thank Dr. Marc Levine and Dr. Susie Fishman-Armstrong of the Sam Noble Oklahoma Museum of Natural History for facilitating access to these ceramic vessel sherd collections from East Texas archaeological sites, and providing work space during our documentation efforts. We are equally grateful for the support provided by the Caddo Nation of Oklahoma for this documentation effort, and we very much appreciate the visit from Phil Cross (Tribal Historic Preservation Officer and NAGPRA Director) of the Caddo Nation during our work. 


\section{References Cited}

Fields, R. C., V. L. Hatfield, D. Burden, E. F. Gadus, M. C. Wilder, and K. W. Kibler

2014 Testing and Data Recovery Excavations at 11 Native American Archeological Sites along the U.S. Highway 271 Mount Pleasant Relief Route, Titus County, Texas. 2 Vols. Reports of Investigations No. 168. Prewitt and Associates, Inc., Austin.

Flynn, P.

1976 A Study of Red-Filmed Pottery from the Clement Site (Mc-8), McCurtain County, Oklahoma. Bulletin of the Oklahoma Anthropological Society 25:127-134.

Hoffman, M. P.

1967 Ceramic Pipe Style Chronology Along the Red River Drainage in Southwestern Arkansas. The Arkansas Archeologist 8(1):4-14.

Jackson, A. T.

1932 Earthen Mound on E. A. Coker Farm in Cass County, Texas. MS on file, Texas Archeological Research Laboratory, The University of Texas at Austin.

Jones, B. C.

1968 The Kinsloe Focus: A Study of Seven Historic Caddoan Sites in Northeast Texas. Master's thesis, Department of Anthropology, University of Oklahoma, Norman.

Perttula, T. K.

2008 The Archeology of the Roitsch Site (41RR16), an Early to Historic Caddo Period Village on the Red River in Northeast Texas. In Collected Papers from Past East Texas Archeological Society Summer Field Schools, edited by T. K. Perttula, pp. 313-628. Special Publication No. 5. Texas Archeological Society, San Antonio.

2015 The Coker Mound (41CS1) in the Sulphur River Basin of East Texas. Journal of Northeast Texas Archaeology 55:1-4.

2017a An Ancestral Caddo Ceramic Vessel from the Molly Cameron Site (41BW18) in the Sulphur River Basin in East Texas. Journal of Northeast Texas Archaeology 75:95-97.

2017b Ceramic Vessels and Other Funerary Objects in the H. R. Taylor (41HS3) Cemetery, Harrison County, Texas. Special Publication No. 46. Friends of Northeast Texas Archaeology, Austin and Pittsburg, MS on file with the author.

2017c The Use of Clay Pigments on Ceramic Vessel Sherds from the Hatchel Site (41BW3) and Comparisons to Ancestral East Texas Caddo Ceramic Vessel Assemblages. Journal of Northeast Texas Archaeology 73:95-102.

Perttula, T. K., B. Nelson, and M. Walters

2012 Caddo Archaeology at the Henry Spencer Site (41UR315) in the Little Cypress Creek Basin of East Texas. Special Publication No. 20. Friends of Northeast Texas Archaeology, Pittsburg and Austin.

20172016 Archaeological Investigations at the T. M. Sanders Site (41LR2), Lamar County, Texas. Journal of Northeast Texas Archaeology 72: 1-42.

Perttula, T. K., R. Z. Selden, Jr., and B. Nelson

2013 Analysis of the Ceramic Sherds from Area C at the Ware Acres Site (41GG31), Gregg County, Texas. Journal of Northeast Texas Archaeology 41:57-79.

Perttula, T. K., M. Turner, and B. Nelson

1997 A Radiocarbon Date from the Coker Mound (41CS1). Journal of Northeast Texas Archaeology 9:17-20. 
Perttula, T. K., M. Walters, and B. Nelson

2016 Caddo Ceramic Vessels from the T. M. Sanders Site (41LR2) on the Red River in Lamar County, Texas. Special Publication No. 41. Friends of Northeast Texas Archaeology, Austin and Pittsburg.

Skinner, S. A., R. K. Harris, and K. M. Anderson (editors)

1969 Archaeological Investigations at the Sam Kaufman Site, Red River County, Texas. Contributions in Anthropology No. 5. Department of Anthropology, Southern Methodist University, Dallas.

Story, D. A., B. Barber, E. Cobb, H. Cobb, R. Coleman, K. Gilmore, R. K. Harris, and N. Hoffrichter

1967 Pottery Vessels. In “The Gilbert Site: A Norteno Focus Site in Northeast Texas,” edited by E. B. Jelks. Bulletin of the Texas Archeological Society 37:112-187.

Suhm, D. A. and E. B. Jelks (editors)

1962 Handbook of Texas Archeology: Type Descriptions. Special Publication No. 1, Texas Archeological Society, and Bulletin No. 4, Texas Memorial Museum, Austin. 